\title{
Peer bullying and substance abuse among first grade university students
}

\section{Üniversite I.sınıf öğrencileri arasında akran zorbalığı ve madde kullanımı}

\author{
Ali Yıldırım*, Yaşar Bilge, Mehmet Karataş, İlhan Çetin, Erdal Özer \\ Departments of Forensic Medicine (Assist. Prof. A. Yıldırım, MD, Assist Prof. E. Özer), \\ Gaziosmanpaşa University, School of Medicine, TR-60200 Tokat, Department of Secondary \\ Education, Division of Social Sciences, (Assist. Prof. M. Karataş, MD). Gaziosmanpaşa \\ University, Faculty of Education, TR-60200 Tokat, Department of Forensic Medicine (Prof. Y. \\ Bilge, MD), Ankara University School of Medicine, TR-06100 Ankara, Department of Medical \\ Education (Assoc. Prof. İ. Çetin, MD), Cumhuriyet Üniversitesi School of Medicine, TR-58140 \\ Sivas
}

\begin{abstract}
Aim. Peer bullying is defined as systematic, deliberate, intentional, and periodic agressive acts inflicted by physically or psychologically stronger children on their weaker peers without any evidence of provocation. In our study, we investigated the incidence of the peer bullying among university students, diversity and the relationship between of the peer bullying and substance use and socio-demographic characteristics. Method. Our study was conducted between April, 11 and May 20, 2011 with 2177 undergraduates training in Faculty of Education, Economics, Administrative Sciences, and Faculty of Science and Literature localized at Central Campus of Gaziosmanpaşa University using cluster sampling method. Based on the results obtained from previous prevalence studies, working with a $45 \%$ sampling distribution was decided upon. Accordingly, questionnaire surveys were applied on 985 students in their classrooms under the observance of a supervisor, and statistical analyses were performed on 964 completed questionnaire forms. Results. Two thirds of our study participants were first grade female students. Mean age of the participants was $19.8 \pm 1.6$ years. A $10 \%$ of all students were smokers, $6.9 \%$ of them were using alcohol. Currently $0.4 \%$ of them were heroin, and cocaine users, while a very small percentage of the students were using thinner $(0.4 \%)$ and cannabis $(0.5 \%)$. Some of the male students stated that they could fight for their girl friends (32\%) or for any friend (30\%). A $22.3 \%$ of all the participants who were mostly male $(40.8 \%)$ and at a lesser proportion female (13.4\%) students expressed that they could fight frequently, and incessantly with those who would swear at them. Apart from verbal violence, in all types of violence, incidence of exposure to violent behaviours has observedly risen in line with the educational level of parents. Mostly among substance abusers $(88.9 \%)$, then alcohol, and tobacco addicts have been exposed to physical violence in decreasing order. Verbal violence was directed mainly to alcohol abusers, while smokers were predominantly subjected to emotional violence. Conclusion. In our study a significant correlation was found between alcohol, and other substance abuses and increased incidence of bullying. In fact, in many studies performed, an association between substance abuse, and criminal acts has been revealed. Social, and individual awareness about the relationship between the substance use, and tendency to commit criminal acts should be created via informative programs encompassing both users, and their families.
\end{abstract}

Keywords: Peer bullying, substance use, school, risk factors

\section{Özet}

Amaç. Akran zorbalığı, içerisinde kışkırtma unsuru olmaksızın aralarında fiziksel ya da psikolojik açıdan güç eşitsizliği olan çocuklardan güçlünün karşı tarafa bilerek ve isteyerek, kasıtll, sistemli bir biçimde belli zaman aralıkları ile uyguladığı saldırılar olarak tanımlanmaktadır. Bu çalışmada üniversite öğrencileri arasında akran zorbalığının sıklı̆̆ı, çeşitliliği ile akran zorbalığının madde kullanımı ve sosyodemografik özellikler arasındaki ilişkisinin araştırılması amaçlandı. Yöntem. Çalışmamız Gaziosmanpaşa Üniversitesi Tokat merkez kampüsünde eğitim görmekte olan 2177 birinci sınıf lisans öğrencilerinde küme örnekleme yöntemi ile \%45 örneklemle 985 öğrenciye sınıf ortamında gözetmen eşliğinde anket uygulanmış ve istatistiksel analizler 964 anket üzerinden 
yapılmıştır. Bulgular. Çalışmamızda araştırmaya katılanların 2/3'si 1. sınıf öğrencilerinin cinsiyet oranlarına paralel olarak kız öğrenci idi. Katılımcıların yaş ortalamaları ise $19,8 \pm 1,6$ idi. Tüm öğrenciler arasında sigara kullananların oranı \%10, alkol kullanan öğrenci oranı \%6,9 iken öğrencilerin halen $\% 0,4$ 'ü eroin ve kokain kullanmakta $\% 0,1$ 'i tiner, $\% 0,5$ 'i ise halen esrar kullandığını ifade etmektedir. Kız arkadaşı için kavga edebileceğini ifade eden erkek öğrencilerin oranı \%32, arkadaşı için kavga edebileceğini ifade eden erkek öğrencilerin oranı ise \%30, kendisine küfreden arkadaşıyla sık sık ve devamlı kavga edeceğini ifade eden öğrenci oranı \%22,3 iken bu oran erkek öğrencilerde $\% 40,8$, kız öğrencilerde $\% 13,4$ olarak bulunmuştur. Sözel şiddet hariç şiddet türlerini hepsinde anne ve baba eğitim düzeyi yükseldikçe şiddetle karş1laşma oranlarında artma gözlenmiştir. Öğrencilerden fiziksel şiddetle karşılaşma oranları en yüksek oranda madde kullananlarda $(\% 88,9)$ bulunmakta iken bunu alkol ve sigara kullanımı izlemektedir. Sözel şiddete ise en çok oranda alkol kullananlar, duygusal şiddetle ise en fazla oranda sigara kullananlar karşılaşmaktadır. Sonuç. Çalışmamızda alkol ve diğer madde kullanımları ile zorbalık arasında anlamlı bir ilişski bulunmuştur. Yapılan birçok çalışmada da madde kullanımı ile suç arasında bir ilişkinin olduğu ortaya konulmuştur. Akran zorbalığı ve madde kullanımı ile ilgili olarak hem kullanıcılar hem de ailelerinin katılımıyla bilgilendirici programlar yapılarak toplumsal ve bireysel farkındalık yaratılmalıdır.

Anahtar sözcükler: Akran şiddeti, madde kullanımı, okul, risk faktörleri

Geliş tarihi/Received: February 06, 2012; Kabul tarihi/Accepted: March 19, 2012

\section{*Corresponding author:}

Dr. Ali Yıldırım, Adli Tıp Anabilim Dalı, Gaziosmanpaşa Üniversitesi Tıp Fakültesi, TR-60100 Tokat. E-mail: aliyildirim64@yahoo.com

\section{Introduction}

Peer bullying is defined as systematic, deliberate, intentional, and periodic agressive acts inflicted by physically of psychologically stronger children on their weaker peers without any evidence of provocation. All physical, verbal, and psychologically aggressive behaviours aiming at provoking fear, anxiety or infliction in the victim are included in this category $[1,2]$. Since bullying behaviours have been usually encountered in schools where children, and adolescents are gathered together for the purpose of getting training, and education, and also because of their adverse effects on social, and developmental processes, they are considered as increasingly challenging issues, and especially in recent years they are attracting public attention more strongly [3, 4]. Global and nationwide studies concerning peer bullying have revealed that social, psychologic, and academic development and weel-being of children are adversely affected $[5,6]$. The unfavourable effects of bullying for both bully, and the victim are not only limited to school years, but they can revive later in one's life as important problems i.e. depression, low self-esteem, and distressing behaviours $[7,8]$. They can come up within a wide spectrum ranging from constructive to destructive behaviours. Peer bullying is classified in the literature as physical, verbal, and emotional bullying, while the first two forms are most frequently seen entities. Physical bullying comprises acts of pushing, kicking, striking, and throwing things at the victim, while verbal bullying can be seen as ridiculing, isolating, insulting, nicknamimg, and rumouring $[2,9,10]$. Recent studies have included electronic (sending unwanted e-mails, and phone messages), and sexual bullying into these globally accepted categories [11, 12]. Studies performed have indicated that personal, familial, psychologic, genetic, and environmental characteristics had an important role in the etiology of bullying, and victimization, and also they reported that substance use could accompany violent behaviours $[5,13,14]$. Some relevant studies have detected that bullies were more frequently using tobacco products, and alcoholic beverages $[2,15]$. Since bullying is a universal problem concerning all people, various world-, and nationwide studies have reported frequencies of peer bullying in a large spectrum ranging between 5, and 75 percent. Although an increase in the number of studies performed recently in our country has been observed, they were not sufficient in number $[2,5,16]$. 
In this study, the frequency, and diversity of peer bullying among first grade university students (freshmen), and its relationship between substance abuse, and sociodemographic characteristics have been investigated.

\section{Material and method}

Our study was conducted between April, 11 and May 20, 2011 with 2177 undergraduates training in Faculty of Education, Economics, Administrative Sciences, and Faculty of Science and Literature localized at Central Campus of Gaziosmanpaşa University using cluster sampling method. Based on the results obtained from previous prevalence studies, working with a $45 \%$ sampling distribution was decided upon. Accordingly, questionnaire surveys were applied on 985 students in their classrooms under the observance of a supervisor, and statistical analyses were performed on 964 completed questionnaire forms. Before performing questionnaire surveys, the students were assured that identity of the responders would not be disclosed to anyone. As a result, 985 students were subjected to questionnaire surveys in their classrooms under the surveillance of their supervisors, questionnaire forms completed by 21 students were excluded from the analyses for various reasons, and 964 questionnaire forms were included in the statistical analysis. For the analysis of data SPSS program was used, results of percentile calculations, and chisquare tests were evaluated. The patients with cigarette using were classified as never used, once tried, dropped. The patients using once-daily or once a year, has been accepted in same category. This was the major limitation of this study.

\section{Results}

Nearly two thirds of our study participants among freshmen were female students in line with gender proportion of the student population. Mean age of the participants was $19.8 \pm 1.6$ years. Parents (mothers 55.8\%; fathers $37.9 \%$ ) were mostly primary school graduates. Only $2.1 \%$ of the mothers, and $16.7 \%$ of the fathers were university graduates. $1.6 \%$ of the participants were motherless, and $5.6 \%$ of them were fatherless. Parents of $95.4 \%$ of the students were living together. Mothers of $9.5 \%$ of the students, and fathers of $76.6 \%$ of them were working for living. On an average participants had $3.5 \pm 1.8$ siblings. As will be seen in Table 1, substance use, trial, and quit rates were rather higher in male students. Tobacco products were used by $10 \%$ of all students, $21.7 \%$ of male, and $3.5 \%$ of female students with statistically significant difference among them. Alcohol consumption rates were also similar. Incidence of alcohol usage was $6.9 \%$ in all participants, increased to $16.3 \%$ in male, and dropped to $1.9 \%$ in female students. Some of the students expressed that they were currently using heroin, and cocaine $(0.4 \%)$, thinner $(0.1 \%)$, and cannabis $(0.5 \%)$. When the relationship between educational level of the parents, and cigarette, alcohol, and consumption rates was analyzed, it is interesting to find increasing consumption rates with higher educational levels of both parents. As can be observed in Table 2, when mothers were lycée, high school, and university graduates, a significant difference in alcohol and substance use was observed, while children of highly educated fathers were more addicted to cigarette smoking. Besides as can be seen in Table 3, addiction levels of male students for three substances were noted to be significantly higher in male students. The state of both being a victim and a perpetrator of peer bullying among students was analysed in Table 4. Participants using brute force against his/her friend for any reason were found to be at relatively very low levels $(1 \%)$. Less than $1 \%$ of the participants expressed that they were frequently, and continuously exposed to brute force by their peers. A $32 \%$ of the male students stated that they could fight for their girl friends. While $30 \%$ the male students indicated that they could fight for his friend(s). Among girls, its corresponding rate was 3.8 percent. A $22.3 \%$ of the students remarked that they would fight frequently, and consistently with their friends who would use abusive language against them. The corresponding rates were found to be $40.8 \%$ in male, and $13.4 \%$ in female students. 
Table 1. Substances used, and their frequencies of usage.

\begin{tabular}{|c|c|c|c|c|c|c|}
\hline & n & $\%$ & $\mathbf{n}$ & $\%$ & $\mathbf{n}$ & $\%$ \\
\hline \multicolumn{7}{|c|}{ Tobacco products $(832) \chi^{2}: 99.6, p<0.001$} \\
\hline Never used & 144 & 48.8 & 412 & 76.7 & 556 & 66.8 \\
\hline Tried once, but never used & 52 & 17.6 & 81 & 15.1 & 133 & 16.0 \\
\hline Quitted smoking & 35 & 11.9 & 25 & 4.7 & 60 & 7.2 \\
\hline Current smoker & 64 & 21.7 & 19 & 3.5 & 83 & 10.0 \\
\hline \multicolumn{7}{|c|}{ Alcohol $(821) \chi^{2}: 90.9, p<0.001$} \\
\hline Never used $n$ & 179 & 61.9 & 462 & 86.8 & 641 & 78.1 \\
\hline Tried once, but never used & 46 & 15.9 & 54 & 10.2 & 100 & 12.2 \\
\hline Quitted alcohol & 17 & 5.9 & 6 & 1.1 & 23 & 2.8 \\
\hline Current user & 47 & 16.3 & 10 & 1.9 & 57 & 6.9 \\
\hline \multicolumn{7}{|l|}{ Heroin (803) } \\
\hline Never used & 278 & 98.6 & 516 & 99.0 & 794 & 98.9 \\
\hline Tried once, but never used & 2 & 0.7 & 2 & 0.4 & 4 & 0.5 \\
\hline Former user & 0 & 0 & 2 & 0.4 & 2 & 0.2 \\
\hline Current user & 2 & 0.7 & 1 & 0.2 & 3 & 0.4 \\
\hline \multicolumn{7}{|l|}{ Cocaine (811) } \\
\hline Never used & 280 & 98.6 & 523 & 99.2 & 803 & 99.0 \\
\hline Tried once, but never used & 1 & 0.4 & 3 & 0.6 & 4 & 0.5 \\
\hline Former user & 0 & 0 & 1 & 0.2 & 1 & 0.1 \\
\hline Current user & 3 & 1.1 & 0 & 0 & 3 & 0.4 \\
\hline \multicolumn{7}{|l|}{ Thinner (815) } \\
\hline Never used & 278 & 96.5 & 522 & 99.1 & 800 & 98.2 \\
\hline Tried once, but never used & 8 & 2.8 & 3 & 0.6 & 11 & 1.3 \\
\hline Former user & 2 & 0.7 & 1 & 0.2 & 3 & 0.4 \\
\hline Current user & 0 & 0 & 1 & 0.2 & 1 & 0.1 \\
\hline \multicolumn{7}{|l|}{ Cannabis (812) } \\
\hline Never used & 266 & 93.3 & 522 & 99.1 & 788 & 97.0 \\
\hline Tried once, but never used & 12 & 4.2 & 4 & 0.8 & 16 & 2.0 \\
\hline Former user & 3 & 1.1 & 1 & 0.2 & 4 & 0.5 \\
\hline Current user & 4 & 1.4 & 0 & 0 & 4 & 0.5 \\
\hline
\end{tabular}

Table 2. Rates of cigarette, alcohol, and illicit substance usage by students stratified according to the educational levels of their parents.

\begin{tabular}{|c|c|c|c|c|}
\hline \multirow[b]{3}{*}{$\begin{array}{l}\text { Types of } \\
\text { Dependence }\end{array}$} & \multicolumn{4}{|c|}{ Educational level of parents } \\
\hline & \multicolumn{2}{|c|}{ Maternal education (\%) } & \multicolumn{2}{|c|}{ Paternal education $(\%)$} \\
\hline & $\begin{array}{l}\text { Up to } \\
\text { lycée }\end{array}$ & $\begin{array}{l}\text { Lycée, and } \\
\text { university }\end{array}$ & $\begin{array}{l}\text { Up to } \\
\text { lycée }\end{array}$ & $\begin{array}{l}\text { Lycée, and } \\
\text { university }\end{array}$ \\
\hline \multirow[t]{2}{*}{ Cigarette } & 9.4 & 12.0 & 7.1 & 12.4 \\
\hline & \multicolumn{2}{|c|}{$\chi^{2}: 1.2, p=0.3$} & \multicolumn{2}{|c|}{$\chi^{2}: 6.7, p=0.01$} \\
\hline \multirow[t]{2}{*}{ Alcohol } & 5.6 & 11.3 & 6.1 & 7.6 \\
\hline & \multicolumn{2}{|c|}{$\chi^{2}: 7.6, \mathrm{p}<0.01$} & \multicolumn{2}{|c|}{$\chi^{2}: 0,7, p=0.4$} \\
\hline \multirow[t]{2}{*}{ Any substance } & & 3.2 & 0.8 & 1.4 \\
\hline & $\chi^{2}: 9.3$ & & \multicolumn{2}{|c|}{$\chi^{2}: 0.6, p=0.4$} \\
\hline
\end{tabular}

Table 3. Frequency of cigarette, alcohol, and illicit substance usage by male and female students.

\begin{tabular}{llc}
\hline $\begin{array}{l}\text { Types of } \\
\text { dependence }\end{array}$ & \multicolumn{2}{c}{ Gender } \\
Tobacco products & 21.7 & Female(\%) \\
& $\chi^{2}: 69.9, \mathrm{p}<0.001$ \\
\hline Alcohol & 16.3 & 1.9 \\
& $\chi^{2}: 59.9, \mathrm{p}<0.001$ \\
\hline Any substance & 2.8 & 0.2 \\
& $\chi^{2}: 11.5, \mathrm{p}=0.001$ \\
\hline
\end{tabular}


In the same table, motives for violent behaviours among students are presented. Only $1.5 \%$ of the participants expressed that their families frequently, and continuously wanted them to engage in violent behaviours, while $26.7 \%$ of the students indicated that television films, and programs played a role in creation of a frequent, and ongoing quarrelsome atmosphere among friends. More than half (51.1\%) of the students said that possession of stabbing, and cutting instruments are motivational factors for aggressive behaviours. Only $2.9 \%$ of the students stated that they had been carrying frequently, and continuously cutting, and stabbing instruments like knives, and jackknives with them for fear of being bullied, while $2 \%$ of the participants had possessed these weapons to inflict violence on others. A $4.3 \%$ of the students said that their friends were carrying stabbing, and penetrating objects with them. With the questionnaire survey, reactive responses of victims to verbal violence have been interrogate Nearly $60 \%$ of the students noted that the school success rates, and self-esteem of the ridiculed students had declined. We used the questionnaire to collect data in our survey. The questionnaire was developed by Prof. Dr. Oğuz Polat and also was not used previously in any publication (Table 5).

Table 4. Evaluation of the victimized and bullying students.

\begin{tabular}{lccccc}
\hline $\begin{array}{l}\text { Question } \\
\text { no.* }\end{array}$ & $\begin{array}{c}\text { Never done / never } \\
\text { exposed to }(\%)\end{array}$ & $\begin{array}{c}\text { A few times / } \\
\text { occasionally (\%) }\end{array}$ & $\begin{array}{c}\text { Frequently } \\
(\boldsymbol{\%})\end{array}$ & $\begin{array}{c}\text { All the time / } \\
\text { yes }(\boldsymbol{\%})\end{array}$ \\
\hline 1 & 955 & 77.7 & 20.8 & 0.7 & 0.7 \\
2 & 956 & 82.4 & 16.3 & 0.6 & 0.6 \\
3 & 952 & 96.4 & 3.2 & 0.2 & 0.2 \\
4 & 952 & 85.6 & 13.9 & 0.1 & 0.4 \\
5 & 952 & 92.3 & 6.6 & 0.7 & 0.3 \\
6 & 957 & 92.4 & 6.7 & 0.7 & 0.2 \\
7 & 955 & 94.1 & 5.0 & 0.6 & 0.2 \\
8 & 950 & 39.3 & 45.3 & 5.8 & 9.7 \\
9 & 898 & 59.8 & 27.7 & 4.0 & 8.5 \\
10 & 952 & 94.0 & 4.5 & 0.6 & 0.8 \\
11 & 950 & 36.8 & 40.8 & 9.6 & 12.7 \\
12 & 954 & 86.1 & 12.3 & 1.4 & 0.3 \\
13 & 949 & 92.5 & 4.8 & 0.5 & 2.1 \\
14 & 956 & 97.3 & 1.3 & 0.2 & 1.3 \\
15 & 950 & 44.9 & 28.3 & 15.9 & 10.8 \\
16 & 942 & 26.5 & 22.3 & 23.1 & 28.1 \\
17 & 950 & 89.6 & 7.6 & 1.1 & 1.8 \\
18 & 953 & 95.5 & 2.5 & 0.6 & 1.4 \\
19 & 949 & 68.8 & 26.9 & 2.6 & 1.7 \\
20 & 955 & 84.5 & 14.0 & 0.7 & 0.7 \\
21 & 955 & 80.6 & 16.6 & 1.5 & 1.3 \\
22 & 954 & 84.5 & 12.2 & 1.7 & 1.7 \\
23 & 956 & 74.7 & 19.7 & 3.1 & 2.5 \\
24 & 953 & 82.5 & 15.5 & 0.8 & 1.2 \\
25 & 955 & 83.9 & 14.5 & 0.4 & 1.3 \\
26 & 950 & 91.1 & 7.6 & 0.5 & 0.8 \\
27 & 952 & 86.7 & 10.9 & 1.2 & 1.3 \\
28 & 947 & 89.3 & 8.2 & 1.0 & 1.5 \\
29 & 949 & 82.3 & 12.9 & 2.6 & 2.2 \\
30 & 951 & 93.6 & 5.2 & 0.7 & 0.5 \\
31 & 951 & 87.9 & 9.6 & 0.7 & 1.8 \\
32 & 943 & 55.9 & 25.7 & 10.5 & 8.0 \\
33 & 948 & 86.3 & 23.5 & 2.2 & 1.8 \\
34 & 942 & 19.6 & 10.8 & 27.8 & 31.5 \\
35 & 905 & 16.8 & 3.6 & 1.5 & 32.7 \\
36 & 943 & 84.8 & & 0.5 & 2.9 \\
37 & 945 & 94.9 & & & 1.0 \\
\hline
\end{tabular}


Table 5. Survey Questions about peer bullying and substance abuse among first grade university students.

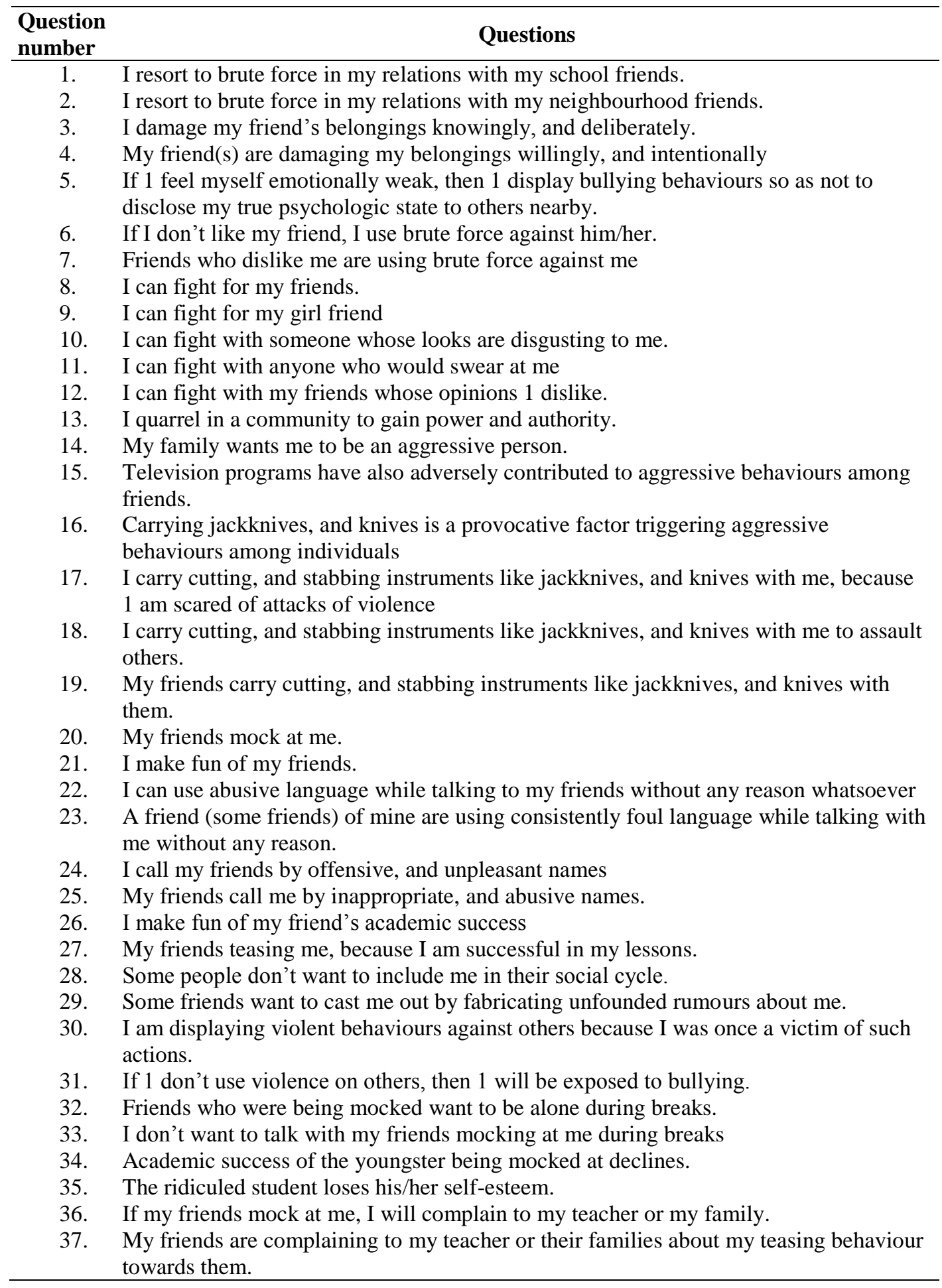

In the study, the correlation between students' exposure to violence, and their gender was analyzed (Table 6). As will be seen, the incidence of all types of violence was found to be significantly higher among male students. More than half $(56.5 \%)$ of the male students, and $30.6 \%$ of the female students expressed that they had encountered physical violence. 
Table 6. Distribution of different types of violence among male, and female students.

\begin{tabular}{lllllllll}
\hline & & $\begin{array}{l}\text { Male } \\
\mathbf{n}\end{array}$ & $\mathbf{\%}$ & $\begin{array}{l}\text { Female } \\
\mathbf{n}\end{array}$ & $\mathbf{\%}$ & $\begin{array}{l}\text { Total } \\
\text { n }\end{array}$ & \% & $\begin{array}{l}\text { X2, p- } \\
\text { Values }\end{array}$ \\
\hline Physical violence & Yes & 124 & 43.5 & 464 & 82.6 & 588 & 69.4 & $\mathrm{X} 2: 135.9$, \\
(n:847) & No & 161 & 56.5 & 98 & 17.4 & 259 & 30.6 & $\mathrm{p}<0.001$ \\
\hline Verbal violence & Yes & 256 & 83.1 & 591 & 93.2 & 847 & 89,9 & $\mathrm{X} 2: 23.3$, \\
(n:942) & No & 52 & 16.9 & 43 & 6.8 & 95 & 10.1 & $\mathrm{p}<0.001$ \\
\hline Emotional violence & Yes & 282 & 91.6 & 605 & 95.3 & 887 & 94.1 & $\mathrm{X} 2: 5.1$, \\
(n:943) & No & 26 & 8.4 & 30 & 4.7 & 56 & 5.9 & $\mathrm{p}<0.05$ \\
\hline
\end{tabular}

In this survey, the impact of educational status of both parents above, and below lycée level on the exposure of the students to the violence was analyzed (Table 7). Only the incidence of verbal violence declined with increased level of maternal education. In all other types of violence, an increase in the rates of victimization was observed with increasing educational levels of the parents.

Table 7. The frequency of exposure to violence classified according to the maternal and paternal educational levels.

\begin{tabular}{|c|c|c|c|c|}
\hline \multirow[b]{3}{*}{ Types of violence } & \multicolumn{4}{|c|}{ Educational level of the parents } \\
\hline & \multicolumn{2}{|c|}{ Maternal education $(\%)$} & \multicolumn{2}{|c|}{ Paternal education(\%) } \\
\hline & $\begin{array}{l}\text { Up to lycée } \\
\text { level }\end{array}$ & $\begin{array}{l}\text { Lycée, and } \\
\text { University }\end{array}$ & $\begin{array}{l}\text { Up to lycée } \\
\text { level }\end{array}$ & $\begin{array}{l}\text { Lycée, and } \\
\text { University }\end{array}$ \\
\hline \multirow[t]{2}{*}{ Physical violence } & 29.6 & 33.8 & 29.7 & 31.3 \\
\hline & $\mathrm{X} 2: 1.3, \mathrm{p}=0.2$ & & $\mathrm{X} 2: 0.3, \mathrm{p}=0.6$ & \\
\hline \multirow[t]{2}{*}{ Verbal violence } & $10.8-1$ & 7.8 & 9.7 & 10.5 \\
\hline & $X 2: 1,6, p=0,2$ & & $\mathrm{X} 2: 0,2, \mathrm{p}=0,7$ & \\
\hline \multirow{2}{*}{ Emotional violence } & 5.2 & 8.9 & 5.5 & 6.3 \\
\hline & $\mathrm{X} 2: 2.8, \mathrm{p}=0.1$ & & $\mathrm{X} 2: 0.3, \mathrm{p}=0.6$ & \\
\hline
\end{tabular}

In Table 8, the correlation between the type of the violence encountered, and nicotine, alcohol, and substance dependence was presented. Accordingly, exposure to physical violence was significantly at a highest rate (88.9\%) among substance users, followed by alcohol, and tobacco dependents. However verbal violence was mostly directed at alcohol users, and emotional violence was predominantly inflicted on smokers.

Table 8. Exposure of students to violence based on their cigarette, alcohol, and substance use.

\begin{tabular}{|c|c|c|c|}
\hline \multirow{3}{*}{ Types of dependence } & \multicolumn{3}{|c|}{$\begin{array}{ll}\text { Type of the violence } \\
\end{array}$} \\
\hline & Physical violence $(\%)$ & Verbal violence $(\%)$ & Emotional violence $(\%)$ \\
\hline & Yes No & Yes No & Yes No \\
\hline \multirow[t]{2}{*}{ Cigarette } & $42.1 \quad 57.9$ & $78.0 \quad 22.0$ & $81.9 \quad 18.1$ \\
\hline & $\mathrm{X} 2: 26.4, \mathrm{p}<0,001$ & $\mathrm{X} 2: 12.4, \mathrm{p}<0,001$ & $\mathrm{X} 2: 26,7, \mathrm{p}<0.001$ \\
\hline \multirow[t]{2}{*}{ Alcohol } & $28.0 \quad 72.0$ & $73.2 \quad 26.8$ & $93.0 \quad 7.0$ \\
\hline & $\mathrm{X} 2: 37.5, \mathrm{p}<0.001$ & $\mathrm{X} 2: 17.4, \mathrm{p}<0.001$ & $X 2: 0.2, p=0.6$ \\
\hline \multirow[t]{2}{*}{ Substance } & $11.1 \quad 88.9$ & $88.9 \quad 11.1$ & $88.9 \quad 11.1$ \\
\hline & $\mathrm{X} 2: 13.1, \mathrm{p}<0.001$ & $\mathrm{X} 2: 0.007, \mathrm{p}=0.9$ & $\mathrm{X} 2: 0.6, \mathrm{p}=0.5$ \\
\hline
\end{tabular}

\section{Discussion}

Peer bullying has been evaluated especially in recent years as a serious problem worldwide. Clinicians, researchers, and instructors are trying very hard to understand the problem, and to generate a solution to eliminate or at least minimize the occurence of these violent behaviours [17]. Studies performed in our country, and in the world about peer bullying exercised at every level of education, have determined different incidence 
rates for bullying. The incidence rates of bullying among students were also estimated by Olweus [4] (5-9\%), by Glover [18] in the UK, and by Hazler [16] in the USA (75\%), however Wang [12] determined the incidence of physical violence as 20.8 percent. Also in our country bullying is a serious problem in schools, and in recent years an increase in the relevant studies performed in our country has been observed. Various incidence rates for exposure of students to physical, verbal or sexual violence during an academic year have been reported (Alikasifoglu et al. [5], 42\%; Özkan and Çifci [10] 29.2\%; Çınkır and Kepenekci, [19], and Piskin [20], 35\%), and the authors reported that bullying was more frequently perpetrated by male students. Also in the present study the students were mostly $(30.6 \%)$ inflicted by physical violence, while the rates of verbal $(10.1 \%)$, emotional (5.9\%) violence, and their cumulative (10\%) incidence were indicated in parentheses. All three types of bullying behaviours were more frequently seen among male students, while physical violence was mostly detected among both male, and female students. This phenomenon can be explained by more easily applicable, and observable nature of physical bullying among students. Although physical violence was mostly detected in our study in compliance with literature findings, our incidence of bullying behaviours was observedly lower than those found in other studies. Level of education, age group of the students, higher rates of migration from other cities among first grade university students, and prolonged adaptation process to new academic environment might account for this lower incidence of bullying in our study. In our study, total incidence of verbal violence among bullying behaviours was $10.1 \%$, while $16.9 \%$ of the male, and $6.8 \%$ of the female students were engaged in such violence. Usage of abusive language $(19.7 \%)$, and ridiculing $(16.6 \%)$ were the most frequently encountered types of verbal harassment. The rates of emotional violence were detected to be $8.4 \%$ in male, $4.7 \%$ in female, and $5.9 \%$ in all responders of the survey. In surveys conducted in schools, emotional violence was more frequently seen among female, while physical, and verbal violence were more often observed among male students $[10,12,21]$. Our study results did not comply with other literature findings with respect to incidence of emotional bullying incidents, and gender difference. This discordance can be explained by higher number of female students participated in the study, and more easily overlooked nature of emotional bullying. Most of the studies performed currently have been focused on peer bullying, and related risk factors. Gender, age, ethnicity, socioeconomic status, construction, and dwelling place of the family, exposure to domestic, and peer violence, membership of a certain group, carrying weapon, stabbing, and cutting instruments, watching scenes of violence on $\mathrm{TV}$, have been associated with peer bullying [22-24]. In addition, some investigations detected a linear correlation between peer bullying, and substance use (i.e. cigarette, and alcohol use) [4, 24, 25]. Bullying behaviours in schools are mostly seen among male students. Although different incidence rates have been observed in many relevant studies performed, higher rates seen among mostly male students are in concordance with the results of our study $[10,12,26$, 27]. Also in this study, the association between the types of violence, and the gender of the victims was significantly stronger among male students. A $30.6 \%$ of female, and $56.5 \%$ of male students expressed that they were inflicted by physical violence. In this study as motivational factors for bullying among students, participants blamed mostly (51.1\%) possession of stabbing, and cutting instrument(s), and secondly violence on television programs $(26.7 \%)$. Carrying stabbing instruments, and violence on television programs have been also implicated for the increase in the incidence of peer bullying in similarly designed studies which complied with the outcomes of our study [24, 28]. Various studies have indicated that students who suffered more frequently from bullying behaviours were in a lower socioeconomic status paralleling with lower educational level of their parents. Similar studies performed in our country have reported lower educational level of the family as a risk factor for peer bullying [10, 29]. In our study, incidence of types of violence was significantly related to the educational level of the parents inconsistent with literature findings. In this study, the incidences of physical, verbal, and emotional violence were higher among students of parents with lycée-university 
graduates when compared with those with lower educational status. In our study, the reason for higher rates of peer bullying in line with the increase in the educational level of the family might be related to increased dependence on smoking, alcohol, and other substances, accordingly. Students being either a perpetrator or a victim of bullying during school years suffer from various emergent problems not only during their school years, but later in their life times. Bullies, and their victims typically display social alienation, depression, decline in their self-esteem, and self-perception, gambling, drug use, dependence on alcohol at an early age, decrease in academic success, and highly risky behaviours $[4,25,30]$. Also in our study, as an interesting phenomenon, higher number of students expressed that academic success rate of the students ridiculed had declined, and their self-esteem decreased in accordance with the results of relevant studies. Many studies performed revealed a significant correlation between substance use, and bullying $[31,32]$. In this study a significant correlation between substance use, and bullying behaviours has been disclosed, and the association between types of violence encountered and dependence on smoking, alcohol, and other substances has been taken into account. Among types of bullying, exposure to physical violence was mostly seen in substance user (88.9), followed by alcoholics, and smokers. Verbal bullying was mostly encountered among alcohol addicts, and emotional bullying among smokers. Wagner et al. [33] found rates of cigarette usage among university students as $23.5 \%$ in male, and $21.3 \%$ in female participants. The corresponding rates in the study by Riou Franca et al. [34] were 19.2, and $14.6 \%$, respectively [33, 34]. In a comprehensive study conducted among first grade students of eight Turkish universities, current smoking rate was found to be 22.5 percent. A study by Şimşek et al. [36] performed among first grade students of Harran University revealed a $25.4 \%$ current smoking rate. Turhan et al. [35] determined the incidence of current smokers as 38.6 percent. Percentages obtained from our study support the findings of the studies conducted in our country, and in the world. In our study cigarette smoking was most prevalent among freshmen (for male, and female students 21.7 , and $3.5 \%$, respectively). Cigarette smoking trial rates were $17.6 \%$ in male, and in $23.3 \%$ female students. $51.2 \%$ of male, and $23.3 \%$ of female students tried smoking at least once in their life times. In our study, and other studies cited, cigarette was the most widely used among substances. Relative to other studies mentioned, the differences in the frequency of cigarette usage, and trial might be explained by regional pecularities, the impact of legislative measures, and informative campaigns in compliance with the smoking ban in our country. Besides, lower incidence of smoking among girls can be associated with our adverse sociocultural attitude against women smokers. Among students after cigarette smoking, alcohol consumption was the most prevalent type of substance abuse. $16.3 \%$ of male, and $1.9 \%$ of female students indicated that they were still using alcohol beverages, while $38.1 \%$ of male, and $13.2 \%$ of female students expressed that they had drunk alcoholic beverages at least once in their life times. A study performed with university students in France reported that $83 \%$ of male, and $66 \%$ of female students had been using alcoholic beverages. The same study indicated that in the USA, in the Harvard University, $71 \%$ of male, and $66 \%$ of female students had been consuming alcoholic drinks [34]. Wagner et al. [33] detected alcohol consumption rates as 74.5 , and $62.8 \%$ in male, and female students, respectively. A study performed by Dorothy et al. [37] demonstrated that students consuming alcoholic beverages had more frequently displayed bullying behaviours against their friends, also engaged in physical violence, and risky conducts. In a study conducted by Şimşek et al. [36] these rates were $31.3 \%$ in men, and $34.2 \%$ in women, while in a study by Turhan et al. [35] 38.6\% of all participant students had used alcoholic beverages at least once in their life times. Both in our study, and in other studies performed in our country alcohol usage rates were lower than those detected in the western world. Differences in alcohol consumption rates might be explained by the impact of ethnic differences [37]. In addition, cultural differences, especially adverse public attitudes, and beliefs towards alcohol consumption might be influential. In our study, $9.6 \%$ of the students had tried narcotic drugs at least once, while $1.8 \%$ of them were current users. When compared with western countries, incidence 
rates of illicit drug use were comparatively lower [22]. In studies performed in various regions of Turkey, slightly higher rates of narcotic drug use have been observed in university students, and adolescents [15, 31]. In our study, among male students mostly cannabis $(1.4 \%)$, and in female students mainly heroin, and thinner $(0.2 \%)$ use were determined. Our incidence rates were nearly similar with those found in other studies performed in our country, but slightly lower than substance use rates seen in other countries [38-40]. This study revealed higher incidence of cigarette, alcohol, and substance use among male individuals. The results of our study resemble to those obtained from other investigations performed among university students in Turkey, and other countries. These gender differences might be explained with conservative cultural factors prevailng in our country.

In conclusion, even though different incidence rates of substance use, and bullying behaviours have been seen in our country, and worldwide, they still remain to be on the current agenda as challenging problems regarding judicial, medical, and social perspectives. Therefore, university students should be regarded as a risk group with respect to substance use, and peer bullying. Public and individual awareness should be raised concerning peer bullying, and substance use with the participation of users, and their families. In line with this goal, a multidisciplinary working environment should be created so as to offer preventive, and curative health care services curtailing popularization of substance use.

\section{Acknowledgement}

We would like to give special thanks to Prof. Dr. Oğuz Polat for permission to use his questionnaire and also guidance and help.

\section{References}

1. Akgün $\mathrm{S}$. Akran zorbalığının anne-baba tutumları ve anne-baba ergen ilişkisi açısından değerlendirilmesi. Hacettepe Üniversitesi Sosyal Bilimler Enstitüsü Yüksek Lisans Tezi, 2005, Ankara.

2. Brunstein Klomek A, Marrocco F, Kleinman M, Schonfeld IS, Gould MS. Bullying, depression, and suicidality in adolescents. J Am Acad Child Adolesc Psychiatry 2007; 46: 40-9.

3. Smith PK, Ananiadou K, Cowie H. Interventions to reduce school bullying. Can J Psychiatry 2003; 48: 591-9.

4. Olweus D. Bullying at school. In: Dunn J (Eds). What we know and what we can do.Cambridge, MA: Blackwell 1993; 384-437.

5. Alikasifoglu M, Erginoz E, Ercan O, Uysal O, Albayrak-Kaymak D. Bullying behaviours and psychosocial health: results from a cross-sectional survey among high school students in Istanbul, Turkey. Eur J Pediatr 2007; 166: 1253-60.

6. Arseneault L, Walsh E, Trzesniewski K, Newcombe R, Caspi A, Moffitt TE. Bullying victimization uniquely contributes to adjustment problems in young children: a nationally representative cohort study. Pediatrics 2006; 118: 130-8.

7. Pace B. Bullying. JAMA 2001; 285: 2158-9.

8. Gökler R. Okullarda akran zorbalığı. Uluslararası İnsan Bilimleri Dergisi 2009; 6: 511-37.

9. Smokowski PR, Kopasz KH. Bullying in school: an overview of types, effects, family characteristics and intervention strategies. Children \& Schools 2005; 27: 101-10.

10. Özkan Y, Çifci EG. Peer Bullying in Primary Schools in Low Socio-Economic Level. Elementary Education Online 2010; 9: 576-86.

11. Land D. Teasing apart secondary students' conceptualizations of peer teasing, bullying, and sexual harassment. School Psychology International 2003; 24: 14765.

12. Wang J, Iannotti RJ, Nansel TR. School bullying among adolescents in the 
United States: physical, verbal, relational, and cyber. J Adolesc Health 2009; 45: 368-75.

13. Crosby R, Salazar LF, Diclemente RJ, Yarber WL, Caliendo AM, Staples-Horne M. Health risk factors among detained adolescent females. Am J Prev Med 2004; 27: 404-10.

14. Kodjo CM, Auinger P, Ryan SA. Prevalence of, and factors associated with, adolescent physical fighting while under the influence of alcohol or drugs. J Adolesc Health 2004; 35: 346.e11-6.

15. Nansel TR, Overpeck M, Pilla RS, Ruan WJ, Simons-Morton B, Scheidt P. Bullying behaviors among US youth: prevalence and association with psychosocial adjustment. JAMA 2001; 285:2094-110.

16. Hazler RJ, Hoover JH, Oliver R. Student perceptions of victimization by bullies in school. Journal of Humanistic Education and Development 1991; 29: 143-50.

17. SS Leff. Bullying and Peer Victimization at School: Considerations and Future Directions. School Psychology Review 2007; 36: 406-12.

18. Glover D, Gough G, Johnson M, Cartwright N. Bullying in 25 secondary schools: Incidenc, impact and intervention. Educational Research 2000; 42: 141-56.

19. Çınkır Ş, Kepenekci-Karaman Y. Öğrenciler arası zorbalık. Kuram ve uygulamada eğitim yönetimi 2003; 34: 236-53.

20. Pişkin M. Akran zorbalığ olgusunun ilkoğretim oğrencileri arasındaki yaygınlığının incelenmesi I. Siddet ve Okul: Okul ve cevresinde cocuğa yonelik siddet ve alınabilecek tedbirler sempozyumu bildiri ozeti 2006, İstanbul.

21. Bjorkqvist K, Osterman K, Hjelt-Back M. Aggression among university employees. Aggressive Behavior 1994; 20: 173-84.

22. Spriggs AL, Halpern CT, Martin SL. Continuity of adolescent and early adult partner violence victimisation: association with witnessing violent crime in adolescence. J Epidemiol Community Health 2009; 63: 741-8.

23. Spencer GA, Bryant SA. Dating violence: A comparison of rural, suburban, and urban teens. J Adolesc Health 2000; 27: 302-5.

24. Firearm injury prevention. American College of Physicians. Ann Intern Med 1998; 128: 236-41.

25. Kaltiala-Heino R, Rimpela M, Rantanen P, Rimpela A. Bullying at school--an indicator of adolescents at risk for mental disorders. J Adolesc 2000; 23: 661-74.

26. Pearl R, Bryan T, Herzog A. Resisting or Acquiescing to Peer Pressure to Engage in Misconduckt: Adolescents Expectations of Probable Consequences. Journal of Youth and Adolescence 1990; 19: 43-5.

27. Sapouna M. Bullying in Greek Primary and Secondary Schools, School Psychology International 2008; 29: 199-213.

28. Sage DR. Peer Violence and Violence Prevention, http://www.uptodate.com (Accesed on April 04, 2012).

29. Cuhadaroğlu ÇF, Canat S, Kılıç E, Şenol S, Rugana N, Öncü B, Gündüz Hoşgör A, Işıklı S, Avc1 A. Adolescent and psychic problems: Study of state determine, Turkey, Science Academy Reports 2004: 4. Ankara: TUBİTAK Pres.

30. Delfabbro P, Winefield T, Trainor S, Dollard M, Anderson S, Metzer J, Hammarstrom A. Peer and teacher bullying/victimization of South Australian secondary school students: Prevalence and psychosocial profiles. $\mathrm{Br} \mathrm{J}$ Educ Psychol 2006; 76:71-90.

31. White HR, Hansell S. Acute and Long-Term Effects of Drug Use on Aggression From Adolescence Into Adulthood. J Drug Issues 1998; 28: 837-58.

32. Altuner D, Engin N, Gürer C, Akyay İ, Akgül A. Madde kullanımı ve suç ilişkisi; kesitsel bir çalışma. Tıp Araştırmaları Dergisi 2009; 7: 87-94.

33. Wagner GA, Stempliuk Vde A, Zilberman ML, Barroso LP, Andrade AG. Alcohol and drug use among university students: gender differences. Rev Bras Psiquiatr 2007; 29: 123-9.

34. Riou Franca L, Dautzenberg B, Falissard B, Reynaud M. Peer substance use 
overestimation among French university students: a cross-sectional survey. BMC Public Health 2010; 10: 169.

35. Turhan $\mathrm{E}$, İnandı $\mathrm{T}$, Özer $\mathrm{C}$, Akoğlu S. Üniversite öğrencilerinde madde kullanımı, şiddet ve bazı psikolojik özellikler. Türkiye Halk Sağlığı Dergisi 2011; 9: 33-44.

36. Şimşek Z, Koruk İ, Altındağ A. Harran Üniversitesi Tıp Fakültesi ve FenEdebiyat Fakültesi Birinci Sınıf Öğrencilerinin Riskli Sağlık Davranışları. Toplum Hekimliği Bülteni 2007; 26; 19-24.

37. Newbury-Birch D, White M, Kamali F. Factors influencing alcohol and illicit drug use amongst medical students. Drug Alcohol Depend 2000; 59: 125-30.

38. Görgün S, Tiryaki A, Topbaş M. Üniversite öğrencilerinde madde kullanma ve anne babaya bağlanma biçimleri. Anadolu Psikiyatri Derg 2010; 11: 305-12.

39. Sutherland I, Shepherd JP. The prevalence of alcohol, cigarette and illicit drug use in a stratified sample of English adolescents. Addiction 2001; 96: 637-40.

40. McCabe SE, West BT, Wechsler H. Trends and college-level characteristics associated with the non-medical use of prescription drugs among US college students from 1993 to 2001. Addiction 2007; 102: 455-65. 